This is a self-archived version of an original article. This version may differ from the original in pagination and typographic details.

Author(s): Žakevičiūtè, Rasa

Title: Rural Livelihood Diversification : A Solution for Poverty in the Post-Soviet Rural Baltic States?

Year: 2019

Version: Accepted version (Final draft)

Copyright: @ 2019 The Authors. Sociologia Ruralis, European Society for Rural Sociology

Rights: In Copyright

Rights url: http://rightsstatements.org/page//nC/1.0/?language=en

Please cite the original version:

Žakevičiūtè, R. (2019). Rural Livelihood Diversification : A Solution for Poverty in the Post-Soviet Rural Baltic States?. Sociologia Ruralis, 59(3), 560-580. https://doi.org/10.1111/soru.12259 


\title{
Rural livelihood diversification: a solution for poverty in the post-Soviet rural Baltic states?
}

\begin{abstract}
This article analyses rural livelihood diversification through a longitudinal follow-up survey, that targets former collective farm workers in Estonia, Latvia and Lithuania. It argues, that between 1995 and 2010 the former collective farm workers employed three distinct livelihood diversification strategies in order to create their living. A wage-based livelihood diversification strategy, which does not include any agricultural practices, was more common among the better-off households. A farm-based livelihood diversification strategy, which does not rely on salaries, was more often employed by the poor. A mixed strategy, that combines both wage income and farm activities, was used by both better-off (above the poverty line) and poor households (below the poverty line). The paper also finds that livelihood diversification and poverty among the researched households have country specific patterns, which coincide with the general rural development in Baltic states.
\end{abstract}

Keywords: Baltic states, diversification, livelihood sources, rural livelihood, poverty

\section{Introduction}

The discussion about rural development in the Baltics is mostly related to the farmers and their agricultural holdings. It is rather one-sided, considering that the rural population reaches up to one third of the total population in Estonia, Latvia and Lithuania and less than nine percent of the population is employed within the agricultural sector (ENRD 2015a; 2015b; 2015c). Quite many of traditionally rural livelihood activities have no monetary value (like farming for their own consumption, gathering natural resources and barter work), therefore the majority of the rural population must seek for other livelihood sources. Consequently, the topics of diversification and alternative livelihood sources are of great importance for the sustainable development of the rural Baltics.

The few studies, which are carried out on rural diversification in the Baltics, focus either on household income diversity (Bezemer, Dirk J. et al. 2003), or most recently, on agricultural and enterprise diversification (Herslund 2007; Jirgena 2008; Kšivickienė and Ribašauskienė 2007; Liscova et al. 2011) and do not offer a comprehensive analysis on the rural livelihood portfolios and especially their changes over time. Previous studies were also mostly based on the concept of a farming household and excluded a large part of the non-farming rural households. Against this background, we want to contribute to the discussion on diversification by analysing rural livelihoods of the former collective farm workers. Our analysis includes both farming and non-farming households, which could generate more comprehensive insights into on rural development. 
The focus of this article is on the rural Baltics. When compared to other post-Soviet countries, the rural areas in the Baltic countries are much smaller in size, economically less differentiated and more dependent on private farming, setting them clearly apart from other post-Soviet states. Estonia, Latvia and Lithuania also chose a clearly different path in agrarian reforms, opting for land restitution following a strict top-down principle (Alanen 2004). While most of the agrarian reforms in the CIS countries were aimed to maintain large farms, land restitution in the Baltics resulted in land fragmentation, small-scale farming and constituted a new socio-economic structure (Hartvigsen 2013; Wegren 2005; Žakevičiūtė 2016). This empirical study is part of a wider longitudinal research investigating the consequences of decollectivisation for Soviet farm workers in the Baltics. The study began in the early 1990s and includes one kolkhoz from each Baltic country. Over a timescale of 20 years, a wealth of data about people's coping strategies and changes in rural livelihoods have been gathered, drawing on kolkhoz archives, official documents, interviews with former kolkhoz workers and a survey conducted in 2010. This article analyses rural livelihood diversification and its possible relation to poverty using data from a survey.

The majority of the former collective farm workers in our study stayed in the same region. Although their children or grandchildren generally tended to move away, former collective farm workers still live in the same area either with the families of their adult children or very often next to them in the same area. Therefore, the rural Baltics can be described as a closely-knit network of relatives or family members of former kolkhoz workmates, who were affected by the post-Soviet rural transformation or past choices of their parents. Since some of the initial transitional failures still overshadow people's lives, the fate and survival strategies of the former collective farm workers are very important whilst evaluating the rural situation. By exploring how people constructed their livelihoods in the past and how these choices associate with the changes of the standard of living over time, we get a more comprehensive picture of the development trends that should be supported or avoided in the future. Therefore, the aim of this study is to shed more light onto rural livelihood diversification on a micro scale. The following research questions guided the analysis: what livelihood portfolios were characteristic for the former collective farm workers in the researched areas? And how are these portfolios linked to the economic situation of the former collective farm workers?

It is proposed that after decollectivisation, former collective farm workers diversified their livelihoods using three distinctive - wage-based, farm-based or mixed - strategies. These livelihood diversification strategies are related to the economic situation of the rural households, since the better-off (above the poverty line) and poor households (below the poverty line) have diversified in different ways. The wage-based livelihood diversification strategy is more common among the better-off rural households, whilst farm-based livelihood diversification strategy is more 
frequently adopted by the poor. This trend was similar in all three researched areas, although country specific patters are also observed.

The paper is organised as follows. Firstly, it begins by identifying the basic concepts and setting a framework for analysis. Next, an overview of the Baltic rural development trends is provided. Thereafter, the paper describes the poverty profiles and livelihood portfolios of the researched kolkhoz workers and analyses the diversification of the livelihood portfolios among the "better-off" and "poor" groups in the researched areas. The paper ends with a discussion and concluding thoughts, which highlight key findings and delineate ideas about the further development.

\section{Rural livelihoods and diversification}

For the most part, the rural livelihood framework is closely related to the analysis of the developing countries, but is more sparsely used in the transition or developed states (Ellis 2000; Helmore and Singh 2001; Kinsella et al. 2000; Scoones 1998). By definition, the concept of livelihood indicates all the possible ways, both monetary and non-monetary, in which people construct their living (Ellis 2000; Helmore and Singh 2001). It consists of capabilities, assets and activities - through assets, namely human, physical, natural, and social capital, people are able to engage into diverse livelihood activities and can create versatile livelihood portfolios (Ellis 2000; Scoones 1998). The focus of this article is on the livelihood activities.

The starting point of the rural livelihood analysis has most typically been a farming household (Błąd 2014; Chaplin et al. 2007; Davis, Junior R. and Bezemer 2003; Ellis 2000; Herslund 2007). It is assumed that when agriculture cannot guarantee enough income for living, farming households turn to diverse portfolios of gainful activities to maintain sustainable livelihoods. This process can stretch through several developmental stages, starting with the shift away from monoculture to the activities beyond agriculture (Chaplin 2000). According to M. Błąd (2014), there are two most commonly used terms to describe this process - diversification and pluriactivity. The latter is defined as all "agricultural and non-agricultural activities performed by farmers or members of a farm household" (Błąd 2014, 46). It is associated with the sources of income and is closely connected to the rural non-farm economy. Diversification, on the other hand, is connected to the place of work - a farm on which different agricultural activities are taking place (for example, produce different agricultural products) or agricultural and other economic activities (for example, a non-agricultural businesses) are combined.

Although these terms underline slightly different aspects, in most of the cases they are used interchangeably. Despite providing useful tools for the analysis of the rural economy, their usage also raises several theoretical and 
practical problems. First and foremost, they do not include activities that are carried out outside the countryside. Considering the fact that a large part of the rural population seeks employment in the urban areas (Hazans 2003a; 2003b), a substantial share of the rural livelihood sources should be excluded from the analysis. The biggest problem, however, arises because of their focus on the farming household.

Most of the scholars of post-Soviet studies agree that rural diversification analysis in the post-Soviet countries should go beyond a farm household model (Chaplin et al. 2004; Herslund 2007; Lerman et al. 2008). Firstly, the majority of the rural population had income from both employment and agriculture throughout the Soviet period (and quite often after it). They were never actually farm households when compared to the ones in the developing or even developed countries. A large part of the agricultural produce in these households is for home consumption, therefore they do not fit the traditional concept of a farming household. Besides, due to the complicated transition period (restitution and privatisation of land and non-land production assets), the post-Soviet countries have much more diverse agrarian structures, which do not fit the farm household model (Chaplin et al. 2004).

Secondly, livelihood diversification in a rural context is generally analysed through two closely intertwined dimensions such as type (agricultural or non-agricultural) and place (on-farm and off-farm) of activity (Chaplin 2000; Davis, Junior and Pearce 2001; Herslund 2007; Lerman et al. 2008). Consequently, it implies two possible routes for diversification - "farm diversification" with (different) agricultural and/or non-agricultural activities on the farm and "employment diversification" consisting of the combination of various activities or jobs off the farm. It is argued that employment diversification, or more precisely employment off the farm, is much more appropriate for the rural diversification analysis in post-Soviet countries, since large parts of the rural population are neither farming professionally, nor engage in agricultural employment (Chaplin et al. 2004; Herslund 2007; Lerman et al. 2008). Additionally, "farm diversification" is promoted politically through the rural development programmes, although "employment diversification" is more common in the post-Soviet countries, which implies its importance for the rural population (Herslund 2007). Taking all this into consideration, in this article we propose using the concept of livelihood diversification, which can be applied to both farming and non-farming households. The analysis of livelihood diversification would include both monetary and non-monetary activities on and off the farm and in or outside agriculture, as well as other non-earned income (social benefits, rent or dividends) of the rural households.

Diversification is often considered as an important way to decrease rural poverty. In the post-Soviet context, poverty alleviation could be realised through on-farm tourism practices, temporary migratory work (for example seasonal or short-term work abroad) or commuting to urban areas (Bezemer, Dirk J. et al. 2003; Herslund 2007; 
Macours and Swinnen 2008). Such practices increase the survival capabilities of the poorer households and, consequently, have an "equalising effect on rural incomes" (Ellis 1998, 18; Bezemer, Dirk J. et al. 2003). By engaging in various activities, usually outside rural areas, poor households get a possibility to exploit all their assets and create more sustainable livelihood portfolios.

Nevertheless, the impact of diversification on rural income raises certain debates. As it is noted by D. Bezemer and colleagues (2005), the combination of various activities does not necessary lead to an increase in livelihood, whereas specialisation more reliably does so. Moreover, diversification is quite often a capital accumulation choice for the better-off households, whereas it is seen as a necessity for the rural poor. Since diversification requires certain skills and assets, wealthier households can engage into profitable activities to accumulate wealth, while poorer households have to settle with labour-intense unprofitable activities, thus increasing rural inequality (Herslund 2007). In addition, considering the unequal regional development in the post-Soviet countries, rural households in the most poverty-stricken areas might often do not have the possibilities for diversification (Chaplin et al. 2004). Therefore, it is important to keep in mind that diversification does not have an undisputable positive effect on rural livelihoods.

\section{The context of rural development in the Baltic states}

Throughout the Soviet era, Estonia, Latvia, and Lithuania had very similar development patterns and were among the high-achievers in the USSR (Alanen 2004; Lerman et al. 2004). Rapid, heavily idealised transitional reforms without clear, consistent or long-term rural policies in the early 1990s, severely damaged rural areas, which negatively affected the Baltic rural economy, undermined rural livelihoods and created a new socio-economic structure (Alanen 2004; Žakevičiūtė 2016). Although certain differences in the post-Soviet development can be clearly seen at the micro level (Aidukaite 2013), the Baltic states display the "same periods or phases of development, albeit with differences in timing" (Lauristin et al. 2011, 129).

Initially, the goal of the Baltic rural reforms was to create family farm based agricultural production, therefore everybody in the countryside was encouraged to enter farming or to expand their agricultural activities (Alanen 2004). Consequently, the number of small-scale farms rapidly increased in all Baltic states, reaching its highest peak in the beginning of 2000s when in Lithuania alone there were nearly 300,000 private farms. Most of these farms, however, were technologically primitive, farming on household plots in very labour-intensive ways, which does not fit the traditional notion of a farm household. Joining the EU can be considered as a starting point of a new rural development period, which resulted in the decrease of both farms and people working in agriculture, 
whilst the size of the agricultural holdings increased. Large-scale agricultural production has re-emerged and has steadily increased in the Baltics, but is not able to absorb the workforce surplus in the countryside. The number of agricultural holdings in the Baltics is still very high, farms are very small and neither competitive nor productive, while the employment in agriculture is amongst the highest in the EU (ENRD 2015a; 2015b; 2015c; European Commission 2015a; 2015b; 2015c).

Small-scale farming in the Baltics is closely related to poverty. Previous research revealed that among the rural population, especially in Lithuania, farmers are more prone to poverty even after receiving EU support (Braziene 2008; Kšivickienė 2006). The most vulnerable group consists of small or average-scale farmers, who were usually pushed towards subsistence farming due to a lack of social and/or economic capital and scarce employment opportunities in the area (Macours and Swinnen 2008; Žakevičiūte 2016). The number of people at risk of poverty or social exclusion in the rural Baltics has always been lowest in Estonia - between 2005-2016 it was rather stable at the 25-29\% line (Eurostat 2018). On the other hand, in Latvia more than half of the rural population was at risk of poverty in 2005 which with some fluctuations decreased to $35 \%$ in 2016 . The Lithuanian percentage decreased gradually over time, but it started increasing again since 2015, leaving the Lithuanian group to be the largest when compared to the other two countries (37.6\% in 2016). Recently, the gap between rural and urban poverty rates has also diminished, especially in Estonia, but it still remains large compared to the old EU member states (European Commission 2008). Moreover, the rural unemployment (15-23\% in 2010) rates in the Baltics, with the slight exception of Estonia, are also one of the highest among the EU countries.

The development of the rural Baltics is strongly influenced by other unfavourable demographical and socioeconomic factors. High mortality and migration rates lead to intense ageing and depopulation, which are most prominent in Latvia (Pavuk 2014). The UN Population Division estimates that between 1990 and 2010, Latvia lost $15.5 \%$, Estonia - $14.4 \%$ and Lithuania $10.1 \%$ of its population (Berzins and Zvidrins 2011). The large gap in life expectancy between women and men makes the demographic situation more problematic, as it results in a predominantly female elderly population. Regional development and economic growth are furthermore affected by low human and social capital, as well as a high prevalence of pessimism and isolation in the Baltic countryside (Alanen 2004; Joiko et al. 2007; Sinnott and Koettl-Brodmann 2015).

With limited possibilities for non-agricultural employment in the countryside, the rural population is pushed towards migration and commuting, especially to the capital areas (Hazans 2003b; Nugin 2014; Pociūtė-Sereikienè et al. 2014). Rural commuting in all three states is rather high, although over generally short-distance (up to 10$20 \mathrm{~km}$ ), since it is hindered by poor transport infrastructure and geographical remoteness (Biosca et al. 2013; 
Hazans 2003a). Considering that most of the rural municipalities in the Baltics are under-developed (Kairyte and Meyers 2010; Ministry of internal affairs 2005; Saktina and Meyers 2007), short distance commuting can be a solution only for those rural areas that are close to large cities. Moreover, the lack of social capital, for example, low level or specialised agricultural education, could prevent the rural population from finding employment in the urban areas.

The integration of the Baltic States into the EU provided a new means of financial support for the rural economy. Although the absorption of the EU rural development support was successful in the previous periods, only a small part (about $10 \%$ in previous programs, up to $14-17 \%$ in the newest $2014-2020$ period) of the development fund was directed towards local development or rural communities (ENRD 2015a; 2015b; 2015c; KoloszkoChomentowska 2018; Ribašauskienè et al. 2007). Moreover, the positive effect of the EU support was mostly experienced by the already financially stable agricultural holdings in economically strong regions, since previous support programmes were "in favour of certain territories, sectors and entrepreneurs" (Saktina and Meyers, cited from Pilvere 2007, 145). The ongoing 2014-2020 Rural Development programmes are also mostly directed towards modernisation, competitiveness and innovation in the agricultural holdings, as well as ecosystems and resource efficiency (ENRD 2015a; 2015b; 2015c). Rural diversification and non-agricultural business development, as part of rural development and poverty reduction measures, are promoted in these programmes too, but their main target is agricultural holdings and agricultural diversification. Since income diversification was shown to be one of the ways of reducing poverty, it is suggested that farmers should include more non-agricultural activities into their livelihood strategies (European Commission 2008; Kšivickienè 2006).

Against this context, where Baltic rural development programmes are focussing on the strengthening of farming units, we attempted to explore the broader rural livelihood profiles in the Baltics states in order to evaluate which rural livelihood diversification portfolios could be useful for a more inclusive process of rural development.

\section{Data and method}

\section{Research areas}

This research is part of a longitudinal study, focusing on the fate of the former collective farm workers in the Baltic countries. Since the early 1990s, three kolkhozes were selected and investigated in detail using various research methods. These collective farms, one from each Baltic state, were typically average large-scale production enterprises in the Baltic states. They were dairy farms located in peripheral south-eastern or eastern areas, which had soil of below average quality and were typical in relation to the average size of farms in each 
country. According to the official kolkhoz records, Estonian (436 members) and Latvian (406 members) collective farms were similar in size, while Lithuanian farm was slightly smaller with 269 members ${ }^{1}$.

The researched collective farms were established in predominantly rural settlements, which are 10 to 20 kilometres away from the municipality centre and about 50 kilometres away from the second largest town in Latvia and Estonia, and about 70 kilometres away from the capital in Lithuania. The local parishes of the former kolkhozes in Lithuania and Latvia are very similar in territory $\left(65.65 \mathrm{~km}^{2}\right.$ in Lithuania and $73.34 \mathrm{~km}^{2}$ in Latvia) and population (694 inhabitants in Latvia and 581 in Lithuania in 2010), and they are in the least developed rural regions. About one third of the parish inhabitants previously worked in the local collective farms. In Estonia the parish is significantly bigger in territory and population (2,658 inhabitants in $231.5 \mathrm{~km}^{2}$ in 2010 data), therefore statistical data should be compared with caution to the other two countries. Even so, the demographic, socioeconomic, agricultural, investment and land resource indicator scores of the former collective farm areas (on the municipal level) in the time of the research were lower than average in all three countries (Kairyte and Meyers 2010; Ministry of internal affairs 2005; Saktina and Meyers 2007).

\section{Data and analysis}

The data for this paper was collected in 2010 using a survey ${ }^{2}$ that inquired after former farm workers' opinions on the dissolution of collective farm as well as their coping strategies and civil activities. It also included questions on household income and livelihood practices that are the focus of this article. The aim of the survey was to complement a previous longitudinal quantitative study with the information directly obtained from the researched population. The survey was conducted over four weeks in February-March.

The survey was intended to reach all workers of the former collective farms who were included into the original kolkhoz lists in the early 1990s. Bearing in mind the time that has elapsed, many people were inaccessible (dead, ailing, moved without record). Altogether, we were able to find 469 individuals from the original lists. However, the focus of this article is on (1) households that (2) stayed in the rural area and (3) were still of the working age at the time of research. Therefore, after carefully selecting and recoding the data, this article is based on the information from 157 households (481 household members in total). This small number of households does not allow for generalisations for the whole country or for all rural Baltics. However, it provides important indicative micro-scale results on rural livelihood diversification and its changes over the period of 20 years which offer the opportunity for the theoretical conceptualisation of post-soviet rural livelihoods. 
The data in this study was collected using a questionnaire. It included questions on household type and size (number of people, children, breadwinners), possession of land (in hectares) and income in 2009. Also, it inquired after livelihood sources (activities that support the household's livelihood, both monetary and non-monetary), social income transfers, household's economic problems, and an evaluation of the household's standard of living in two periods of time - in the first period from the privatisation of kolkhoz until 1995 (referred as 1995 in the article) and the last years until 2009 (referred as 2009 in the article). Some of these variables were scaled or converted into indices better suited to our analysis (see Appendix 1). The unit of analysis in this paper is a household.

Poverty in this paper was measured using self-reported household's equivalised disposable income (per capita) in 2010. In the article, we compare below the poverty line income to above the poverty line income households. The poverty line (at risk-of-poverty threshold) for each Baltic country was based on the official statistics (Statistics Estonia 2017; Statistics Latvia 2017; Statistics Lithuania 2017). In 2010, the at risk-of-poverty threshold in Estonia was 279.90 euros, in Latvia - 209.75 euros and in Lithuania - 202 euros.

To start with, we used descriptive statistics, comparative statistics and variance tests to answer the question of what livelihood portfolios were characteristic for the former collective farm workers in the researched areas as well as how they changed over time. The livelihood sources were compared across two points of time using the analysis of variance (one-way ANOVA) to test for the differences between the countries. Doing so we can estimate the general livelihood diversification trends among the researched group.

Next, we distinguished between wage-based (diversifying household, with wage income and other sources, farming excluded), farm-based (diversifying household, with farming activities and other sources, wage income excluded) and mixed (diversifying household, combining both wage income, farming, and other sources) livelihood diversification types. This new variable of diversification strategies was used as an independent variable (factor) in the analysis of variance to test for differences between the groups. The variables presented in the Appendix 1 were used as dependent variables. Finally, to evaluate how these strategies are linked to the economic situation of the former collective farm workers, we assessed the livelihood portfolios of the poor (below the poverty line) and compared them with the portfolios of the better-off (above the poverty line) households. The analysis was performed using IBM SPSS 24 statistical program.

\section{Diversification, livelihood sources, and poverty among the studied rural households}

Poverty among former collective farm workers 
More than 20 years after privatisation, the former collective farm workers are facing poverty. Out of all households we managed to reach in 2010 , more than one third were at-risk-of-poverty. Poverty was most widely spread in Latvia where more than half of the households had an income below the poverty line. In the Estonian case we found the lowest share of households below the poverty line, although it was still nearly $30 \%$. Even though the Latvian case had more people at-risk-of-poverty, income inequality was highest in Lithuania. Moreover, poverty in Lithuania was much deeper - the lowest income quintile households received only $35.7 \%$ of the poverty line income, as opposed to $53.4 \%$ in Latvia or $70.3 \%$ in Estonia.

Despite these differences, the researched households had many similarities in their poverty profiles. Like in other societies, poverty in the researched areas depends on household size and its structure. Larger households were in deeper poverty compared to single residents, parents with children were more often at risk of poverty when compared to the households without children. Poor households encountered more economic problems and received more social benefits, compared to the better-off households. Unexpectedly, however, also the highest income quintile households in all three countries encountered substantial economic problems (two to three on average). Considering that our research inquired about hardships in everyday life and not consumption of luxury goods, this result among the well-off population is quite alarming. These households had problems paying for clothing, health care, the education of children and even food, however, they did not have problems which could increase social exclusion - most of them had a phone, computer and/or a car. The later problems were more prominent among the poorest households, which not only indicates deprivation, but may also lead to further isolation and poverty.

Overall, the results are very similar to the actual poverty trends in the countries and portray general poverty patterns in the rural Baltics in the 2000s. We will now proceed to analyse livelihood diversification strategies in our researched areas.

\section{The diversification strategies and livelihood portfolios among studied households}

The majority of the former collective farm workers in our researched areas used multiple activities in constructing their livelihood and on average depended on at least two different activities (Table 1). As seen from the Table 1, the rural livelihood portfolios most typically relied on wage income, farming (mostly for own consumption), social benefits and the gathering of natural products. The large share of food that was self-grown and gathered among our respondents supports the importance of non-monetary income in rural livelihoods. The results were similar in all three countries, although the Latvian participants, when compared to Estonian and especially Lithuanian ones, 
had significantly more diversifying households in both periods of time. This coincides with the greater importance of farming, whereas households, engaged into agricultural activities, had statistically more income sources (3.38 $\pm 0.88)$, when compared to the households without agricultural activities $(1.62 \pm 1.02)$ as evidenced by one-way $\operatorname{ANOVA}\left(\mathrm{F}(1,152)=128.231, \mathrm{p}=.000, \eta^{2}=.458\right)$.

When comparing the rural livelihood portfolios of 1995 and 2009, it is clear that rural diversification is decreasing (paired t test (2009-1995): mean difference $=-.274, t=-3.220, \mathrm{df}=156, \mathrm{p}<0.01)$. The trend, which can be seen in the Table 1, was observed in all three Baltic states, albeit with differences in intensity. Although the diversifying households continue to have similar amounts of livelihood sources, their share among the researched population decreases. This decrease is biggest in Lithuania and smallest in Estonia, with Latvia being in the middle. The decrease of diversifying households could be partly treated as an effect of ageing. Nevertheless, the majority of the households that had stopped the diversification practices started to rely solely on wages (72.2\%), which could, alternatively, mean that wage income has become a sufficient means of subsistence for these households. While analysing our data, we reached the conclusion that it is more important how households diversify their livelihood, instead of asking if they do so. Consequently, three different - wage-based, farming-based and mixed - livelihood diversification strategies were identified to explain diversification differences among the researched households. The first one, the wage-based strategy, describes those households that received wages from employment and had other livelihood activities, but did not engage into agricultural practices at all. The second one, on the contrary, would indicate farming activities without any wage income, while households using the last strategy would combine both wage income and agricultural practices of some sort. Based on variance tests, these strategies vary by the average amount of livelihood activities both in 1995 and 2009, the number of encountered economic problems, evaluation of standard of living and income per capita (see Table 2). This result, with slight exceptions, is similar in all three researched areas although it is not statistically significant in all instances.

As can be seen in Table 2, the mixed livelihood diversification strategy, which combined employment and agricultural activities, was most common among the diversifying households in both 1995 and 2009 . Unfortunately, our research did not inquire about the reasons behind employing particular sources of livelihood; therefore, we cannot estimate the importance of each livelihood activity for the household. However, it seems that only a small part of households upholding mixed-strategy are traditional farming households, since most of them produce for household consumption and only $13.7 \%$ engage in market-based agriculture.

The farm-based livelihood diversification strategy, on the other hand, indicates a more traditional farming household - there is strong tendency towards an entrepreneurial income, barter work (work in exchange for 
services or products) and unofficial income (getting paid for work without registering employment), as well as larger share of market-based agriculture (although only 17.1\%). The wage-based livelihood diversification strategy mostly combines salary and social income transfers or gathering natural products, which are both rather supplementary than necessary livelihood sources.

Next, we will analyse how these distinct diversification strategies could be related to poverty in the researched areas.

\section{How diverse livelihood portfolios are connected to poverty?}

Poor households diversify more often, compared to the better-off. Out of all households below the poverty line, $87.7 \%$ had more than one livelihood source, while the same was true for only $67.1 \%$ of the households above the poverty line . In case of no-diversification, the better-of households relied exclusively on wage income, while the poorer households depended on social benefits or farming.

As demonstrated in the Table 2, the income per capita varied among households employing different livelihood diversification strategies. The households with wage-based diversification in 2009 had statistically more income per capita (400.64 \pm 329.50 ), when compared to the other households, as evidenced by one-way ANOVA ( $\mathrm{F}(2$, $\left.97)=5.172, p=.007, \eta^{2}=.096\right)$. This would suggest that the wage-based diversification strategy is the most gainful economically, since it also indicates fewer economic problems and a more positive evaluation of the standard of living. Nevertheless, there were also several very poor households that relied on the wage-based diversification; therefore, having wage income in the household does not necessarily lead to a better standard of living.

In order to understand how livelihood sources and diversification strategies were related to economic success or poverty, we also analysed their difference among households above and below the poverty line (Figure 1). In Figure 1, livelihood sources and diversification strategies of those households in 2009 which were either poor or not, are presented for two different points in time - 1995 and 2009. As evident from the graph, the livelihood diversification patterns were different among these households and changed over time. The wage-based livelihood diversification strategy was more typical for the better-off households. The farm-based livelihood diversification, on the other hand, was found more often among the poor households and was closely related to social income transfers. The households with a farm-based livelihood diversification strategy had also more diverse livelihoods and generated on average the lowest income per capita, as can be seen in the Table 2. The mixed diversification 
portfolio was found among both poorer and better-off households, although its share among the latter group is slowly decreasing.

Figure 1 also indicates that over time better-off households discontinued some of their previous activities (engagement in agriculture, gathering nature products) and stopped relying on social income transfers. The poor households, on the other hand, drifted further towards the farm-based livelihoods, although the prevalence of wage-income among these households also increased over time. It is important to note the increasing share of entrepreneurial activities (for example, shops, rural services or other businesses) in the farm-based diversification strategy among both better-off and poorer households. This increase could indicate the expansion of a non-farm economy, since the majority of the researched households with entrepreneurial income were not engaged in market-based agriculture.

The livelihood diversification patterns among the poor and better-off households are similar across the countries with some small differences. In Estonia and Lithuania, poor households were more likely to engage in farm-based diversification when compared to the better-off households. The better-off households, on the other hand, were more likely to combine both wage labour and farming for household consumption (mixed-diversification) or rely on wage income. In Latvia, the livelihood diversification pattern was more similar among households both above and below the poverty line. Although, the better-off households were more likely to engage in the wage-based strategy and poor households chose the farm-based one, the distinction was not as striking as in the other two countries. Compared to Estonia or Lithuania, the share of the better-off households relying on farm-based livelihood diversification was also higher in Latvia. This could indicate that Latvian households are more similar to the traditional farming households, where livelihood is more often related to market-based agriculture.

\section{Conclusions and discussion}

This study describes the livelihood diversification patterns that are typical for the former collective farm workers in the rural Baltics. In doing so we looked beyond farm based activities and suggested a more inclusive concept of a rural livelihood. The study revealed that rural households tended to rely on a single type of activity over time, and discontinued some of their diverse livelihood activities. The better-off households tended to rely on wage income, whereas poor households tended to rely on farming, entrepreneurial activities or social benefits. It was found that diversification alone (more or less activities) is not enough to guarantee sustainable rural livelihoods. Similarly to other studies, the poor households in our research diversified more compared to the better-off households (Bezemer, Dirk J. et al. 2003; Bezemer, Dirk et al. 2005; Herslund 2007). Diversification alone is, 
hence, not the solution. What is more important is how the livelihood portfolios are constructed and what activities are available for the rural population.

Rural livelihood diversification and poverty vary across the selected countries. In Estonia, poverty and rural diversification patterns are closest to the ones in the Western countries: with rural poverty being less prominent and less substantial, and a moderate frequency of livelihood diversification that differs between poor and betteroff household strategies. Moreover, there is strong evidence of a trend towards leaving agriculture. The Latvian livelihood diversification and poverty is similar to the Russian patterns (Lerman et al. 2008; O'Brien et al. 2005). Latvian households relied on farming income more often, the importance of livelihood diversification was stronger, whilst poverty was much more widespread. Moreover, the Latvian case is rather exceptional, since both poor and rich households had very similar livelihood strategies. The Lithuanian population had a considerably lower standard of living and experienced a deeper poverty. They had significantly less diverse livelihoods, there was no trend of leaving agriculture and farming was widespread. There is evidence, however, that rich households are turning towards wage-income based livelihood portfolios like in Estonia (especially among non-diversifying households), even though the significance of farming for rural livelihoods is unmistakable. Nevertheless, it has to be noted that these country specific patterns do not indicate causal relationships as they were not tested in our research.

One of the main findings of the paper is the distinction between the three different livelihood diversification strategies that can be related to the economic situation of the rural households. Over a 20-year timeframe, the better-off households of the former collective farm workers drifted towards the wage-based livelihood diversification, while the poor (below the poverty line) households were more likely to rely on a farm-based livelihood. The mixed strategy, which combines both wage income and farming, was the most common diversification strategy prominent amongst both the poor and the better-off households.

This prevalence of the mixed portfolio and general importance of farming, be it for own consumption or selling the surplus production, can indicate two opposite factors. Firstly, it can mean that farming is economically necessary for the survival of the household. Rural families with low monetary income can rely on their farm to ensure food security of the household, while selling the agricultural surplus to the state or through alternative food markets could guarantee an additional income (Blumberg 2018). Since farming is not economically necessary for the better-off households (Žakevičiūtė 2016), it could be assumed that they are maintaining agricultural practices for completely different reasons. Therefore, a second factor could be a "continuational orientation" (Lauristin et al. 2011) prominent in the Baltic states, which idealises small-scale farming (Alanen 2004; Žakevičiūtè 2016). 
Moreover, ecological reasons cannot be denied. This, in turn, raises questions about the relevant importance of the income from farming or wages in the household budget which was not part of our study.

These results of our study should be evaluated with caution, since this paper is based on rather small samples that include only small share of the farm workers that used to work in the collective farms. We are unable to draw general conclusions, nevertheless, the study allows us to identify diversification strategies that help interpreting national rural development trends and differences between countries. Using this study in evaluating livelihood diversification at the micro scale advances our knowledge of the rural population that can be further tested in future studies.

Overall, even taking the substantial EU support into account, the rural population in the Baltics is generally poor. When we speak about the rural Baltics, we usually come across a stereotype of an old, poor, socially excluded and alcoholic peasant who is posed as a "rural other" in contrast to the modern, and therefore usually urban, citizen (Juska 2007). That peasant, however, is entangled a web of intertwined problems, which have not been solved in more than 20 years of independence. Firstly, there is a poverty-farming paradox. The more the person is poor, the more likely they are to engage into small-scale farming, as it was also evidenced in our research. However, smallscale farming pushes them into deeper poverty.

The majority of the researched households following a farm-based diversification strategy cannot even be considered as "small or average-scale farmers" (Žakevičiūtė 2016) in the social structure of the Baltic countryside. Moreover, around $25 \%$ of the registered small or average farms in Estonia do not produce anything or have any on-farm activities (European Commission 2015a). Considering the general marginalisation of small-scale semisubsistence farming in the EU political discourse (Mincyte 2011), political and financial support, as well as assessment of the Baltic rural development, based on the notion of the agricultural holding is not relevant at all. Furthermore, as support from the rural development programmes does not reach the people that are most in need of it (Koloszko-Chomentowska 2018; Kšivickienė and Ribašauskienė 2007; Pilvere 2007) and people fall out to the "grey zones of welfare" (Knudsen 2015, 17), poor households are forced to increasingly rely on unprofitable agricultural practices.

This, in turn, indicates not only the failed family farm project in the rural Baltics, but also points at the reversed trend with the political turn towards large scale commercial farming. The rural development programmes of all Baltic countries increasingly support modernisation and enlargement as well as farm cooperation. Therefore, the future of small-scale farming can be seen to fulfil only a recreational or food security function of the household. As the development of over 20 years in the researched areas demonstrates, small-scale farming cannot be 
considered as a profitable strategy of the household's livelihood. The small-scale farmers, nevertheless, could opt for ecological farming, since it is usually carried out in smaller agricultural holdings and is more likely to attain the much needed EU support (Statistics Estonia 2017; Statistics Latvia 2017; Statistics Lithuania 2017). More research, however, is needed to evaluate the economic costs and benefits of ecological farming for the small-scale farms.

Secondly, the rural Baltics also struggle with the ongoing demography-economy problem where job opportunities in the rural areas are scarce, therefore, young people tend to leave or find employment in the urban areas and commute to work (Hazans 2003a; Nugin 2014; Pociūtè-Sereikienè et al. 2014). Consequently, the incentives to create new jobs in the rural areas are low, since the residual rural labour force lags behind in the necessary knowledge, skills and competences with no possibilities for further education or training (European Commission 2015c; 2015a; 2015b).

The level of human and social capital in the rural areas is a very relevant topic for the present-day development. As the previous study from our areas have shown, former kolkhoz workers with higher education and better professional experience from the Soviet times were able to sustain larger family farms or more successful businesses and were generally "the winners" in the post-Soviet transformation (Žakevičiūtè 2016). Therefore, in order to raise the much-needed knowledge and skills, the life-long learning possibilities and professional training of the rural population is of a particular importance.

Even so, these opportunities must be provided within a close proximity or in the locality itself. The majority of the employed people in our research were working either in the local village or at the municipality's centre (10$20 \mathrm{~km}$ from home), which is consistent with the general trends of the commuting in the Baltics. Since the rural economies in the transition states are rather limited and commuting is limited to short-distances (Hazans 2003a; Pociūtè-Sereikienè et al. 2014), there is a need for broader economic opportunities and possibilities to strengthen household assets at the municipal level. In this case, the poorer households would have more chances to find employment closer to their living area. Bringing more possibilities closer to people might be crucially important for the poor households, since in our study the majority of them did not have either means of communication (phone or computer) or transportation (car).

Overall, the rural Baltic problems are not being studied enough or thoroughly. Most of the demographic or socioeconomic processes are studied in contrast to the urban areas, while other studies focus solely on farms and their practices. Policy planning and rural understanding at the political level are also not adequate, since it relies too much on the concept of the agricultural holdings or the activities of the local rural communities. Therefore, further 
studies on rural livelihood portfolios of various socio-economic groups could provide a fuller picture of rural development and its achievements, as well as its impact on rural livelihoods in the Baltic countryside.

\section{Notes}

${ }^{1}$ Lithuania, compared to Estonia or Latvia, had on average smaller collective farms (Lerman 2001). Therefore, smaller Lithuanian collective farm in our study is not an exception.

${ }^{2}$ This survey is part of the longitudinal study along a 20-year timescale. Collective farms under investigation were researched since early 1990s using longitudinal monitoring, based on kolkhoz archives and official documents (data collected in 1990, 1995, 1999 and 2005), a survey (in 2010) as well as qualitative interviews.

\section{Acknowledgements}

This study is part of the research project "The Decollectivization of Agriculture in the Baltic Countries from a Psychological and Sociological Point of View." The generous financial support provided by the Academy of Finland is gratefully acknowledged. The author wishes to thank Professor Terhi-Anna Wilska, the editor Bettina Bock and the editors of this special issue for their valuable comments and help in preparing this manuscript.

\section{Disclosure statement}

No potential conflict of interest was reported by the author.

\section{References}

Aidukaitè, J. (2013) Social policy changes in the three Baltic states over the last decade (2000-2012). Ekonomika 92 (3) pp. 89-104.

Alanen, I. (2004) The transformation of agricultural systems in the Baltic countries - a critique of the World Bank's concept. Pp. 5-57 in I. Alanen. Mapping the rural problem in the Baltic countryside: transition processes in the rural areas of Estonia, Latvia and Lithuania (Aldershot: Ashgate).

Berzins, A. and P. Zvidrins (2011) Depopulation in the Baltic states. Lithuanian Journal of Statistics 50 (1) pp. $39-48$.

Bezemer, D., K. Balcombe, J. Davis and I. Fraser (2005) Livelihoods and farm efficiency in rural Georgia. Applied Economics 37 (15) pp. 1737-1745.

Bezemer, D.J., J. Rutkauskaite and R. Zemeckis (2003) Income diversity in rural Lithuania: benefits, barriers, and incentives (London: Centre for the Study of Economic and Social Change in Europe). 
Biosca, O., K. Spiekermann and M. Stępniak (2013) Transport accessibility at regional scale. EUROPA XXI 24 pp. 5-17.

Błąd, M. (2014) Pluriactivities on family farms. Wieś i Rolnictwo 4 (165) pp. 45-60.

Blumberg, R. (2018) Alternative food networks and farmer livelihoods: a spacializing livelihoods perspective. Geoforum 88 pp. 161-173.

Braziene, R. (2008) Study on poverty and social exclusion in rural areas. Country: Lithuania (European Communities: European commission).

Chaplin, H., M. Gorton and S. Davidova (2007) Impediments to the diversification of rural economies in Central and Eastern Europe: Evidence from small-scale farms in Poland. Regional Studies 41 (3) pp. 361-376.

Chaplin, H., S. Davidova and M. Gorton (2004) Agricultural adjustment and the diversification of farm households and corporate farms in Central Europe. Journal of Rural Studies 20 (1) pp. 61-77.

Chaplin, H. (2000) Agricultural diversification: a review of methodological approaches and empirical evidence (London: University of London).

Davis, J. and D. Pearce (2001) The non-agricultural rural sector in Central and Eastern Europe. Pp. 111-130 in C. Csaki and Z. Lerman. The challenge of rural development in the EU accession countries. Third World Bank / FAO EU accession workshop (Washington, D.C.: The World Bank).

Davis, J.R. and D.J. Bezemer (2003) Key emerging and conceptual issues in the development of the RNFE in developing countries and transition economies (Kent: Natural Resources Institute).

Ellis, F. (2000) Rural livelihoods and diversity in developing countries (Oxford: Oxford university press).

Ellis, F. (1998) Household strategies and rural livelihood diversification. The journal of development studies 35 (1) pp. 1-38.

ENRD (2015a) 2014-2020 Rural Development Programme: Key facts \& figures. Estonia. Available: https://enrd.ec.europa.eu/sites/enrd/files/ee_rdp_qnt_summary_v1_2.pdf [2019, May 27]. 
ENRD (2015b) 2014-2020 Rural Development Programme: Key facts \& figures. Latvia. Available: https://enrd.ec.europa.eu/sites/enrd/files/lv_rdp_qnt_summary_v1_2.pdf [2019, May 27].

ENRD (2015c) 2014-2020 Rural Development Programme: Key facts \& figures. Lithuania. Available: https://enrd.ec.europa.eu/sites/enrd/files/lt_rdp_qnt_summary_v1_1.pdf [2019, May 27].

European Commission (2015a) Factsheet on 2014-2020 Rural Development Programme for Estonia. Available: http://ec.europa.eu/agriculture/rural-development-2014-2020/country-files/ee/factsheet_en.pdf [2019, May 27].

European Commission (2015b) Factsheet on 2014-2020 Rural Development Programme for Latvia. Available: http://ec.europa.eu/agriculture/rural-development-2014-2020/country-files/lv/factsheet_en.pdf [2019, May 27].

European Commission (2015c) Factsheet on 2014-2020 Rural Development Programme for Lithuania. Available: http://ec.europa.eu/agriculture/rural-development-2014-2020/country-files/lt/factsheet_en.pdf [2019, May 27].

European Commission (2008) Poverty and social exclusion in rural areas. Final study report (European Commision: Directorate-General for Employment, Social Affairs and Equal Opportunities).

Eurostat (2018) People at risk of poverty or social exclusion by degree of urbanisation [Homepage of Eurostat], [Online]. Available: http://appsso.eurostat.ec.europa.eu/nui/show.do?dataset=ilc_peps13\&lang=en [2019, May 27].

Hartvigsen, M. (2013) Land reform in Central and Eastern Europe after 1989 and its outcome in the form of farm structures and land fragmentation Food and Agriculture Organization of the United Nations, FAO).

Hazans, M. (2003a) Commuting in the Baltic states: patterns, determinants and gains (Bonn: ZEI Working paper).

Hazans, M. (2003b) Determinants of inter-regional migration in the Baltic countries (Bonn: Zentrum für Europäische Integrationsforschung). 
Helmore, K. and N. Singh (2001) Sustainable livelihoods: building on the wealth of the poor (Bloomfield, CT: Kumarian Press).

Herslund, L. (2007) Rural diversification in the Baltic countryside: a local perspective. GeoJournal 70 (1) pp. 4759.

Jirgena, H. (2008) Diversification prospects in rural areas of Latvia (Jelgava: Latvia University of Agriculture).

Joiko, C., M. Petzoldt and K. Menrad (2007) Impact of regional demographic factors on the agriculture and rural economies (Straubing: University of Applied Sciences Weihenstephan).

Juska, A. (2007) Discourses on rurality in post-socialist news media: The case of Lithuania's leading daily “Lietuvos Rytas” (1991-2004). Journal of Rural Studies 23 (2) pp. 238-253.

Kairyte, E. and W.H. Meyers (2010) Territorial indicators for rural development: targeting lagging areas in Lithuania. Management Theory and Studies for Rural Business and Infrastructure Development 20 (1) pp. 45-52.

Kinsella, J., S. Wilson, F. De Jong and H. Renting (2000) Pluriactivity as a livelihood strategy in Irish farm households and its role in rural development. Sociologia Ruralis 40 (4) pp. 481-496.

Knudsen, I.H. (2015) Grey zones of welfare: Normative coping strategies in rural Lithuania. Journal of Eurasian Studies 6 (1) pp. 17-23.

Koloszko-Chomentowska, Z. (2018) Financing of agriculture and rural areas in the Baltic states. Pp. 772-778 in M. Bozina Beros, N. Recker and M. Kozina. 27th International Scientific Conference on Economic and Social Development (Varazdin: Varazdin Development and Entrepreneurship Agency).

Kšivickienè, D. and E. Ribašauskienė (2007) Ūkinès veiklos įvairinimo kaime sociologinis vertinimas. Žemès ükio mokslai 14 pp. 19-26.

Kšivickienè, D. (2006) Skurdo apraiškos Lietuvos kaime. Žemės ūkio mokslai 1 (Priedas) pp. 81-91.

Lauristin, M., Z. Norkus and P. Vihalemm (2011) On the sociology's contribution to knowledge of the Baltic way. Sociologija. Mintis ir veiksmas (2) pp. 128-155. 
Lerman, Z., E. Serova and D. Zvyagintsev (2008) Diversification of rural incomes and non-farm rural employment: Survey evidence from Russia. The Journal of Peasant Studies 35 (1) pp. 60-79.

Lerman, Z., C. Csáki and G. Feder (2004) Agriculture in transition: land policies and evolving farm structures in post-Soviet countries (Lanham, MD: Lexington Books).

Lerman, Z. (2001) Agriculture in transition economies: from common heritage to divergence. Agricultural economics 26 (2) pp. 95-114.

Liscova, A., B. Rivza and M. Kruzmetra (2011) Farm diversification models: causes and tendences. Management Theory and Studies for Rural Business and Infrastructure Development 26 (2) pp. 155-159.

Macours, K. and J.F.M. Swinnen (2008) Rural-urban poverty differences in transition countries. World Development 36 (11) pp. 2170-2187.

Mincyte, D. (2011) Subsistence and Sustainability in Post-industrial Europe: The Politics of Small-scale Farming in Europeanising Lithuania. Sociologia Ruralis 51 (2) pp. 101-118.

Ministry of internal affairs (2005) Regional development strategy of estonia 2005-2015 (Tallinn: Regional development department of the Ministry of internal affairs).

Nugin, R. (2014) "I think that they should go. Let them see something". The context of rural youth's out-migration in post-socialist Estonia. Journal of Rural Studies 34 pp. 51-64.

O'Brien, D.J., V.V. Patsiorkovski, S. Wegren and S.K. Wegren (2005) Poverty and adaptation in rural Russia. Pp. 95-126 in S.K. Wegren. Rural adaptation in Russia (Oxon: Routledge).

Pavuk, O. (2014) Retirement economy within the context of problems of demography and the labour market in the Baltic States. Economic Science for Rural Development 36 pp. 110-117.

Pilvere, I. (2007) EU agriculture structural fund support results in Latvia. Žemès ūkio mokslai 14 (Priedas) pp. 145-150.

Pociūtè-Sereikienė, G., E. Kriaučiūnas and R. Ubarevičienė (2014) Peripheralisation trends in rural territories: the case of Lithuania . Studies in Agricultural Economics 116 pp. 122-130. 
Ribašauskienė, E., E. Kairytė and W.H. Meyers (2007) Territorial Dimensions of Lithuanian Rural Development Plan 2004-2006: Lessons for 2007-2013. Žemès ūkio mokslai 14 (Priedas) pp. 11-18.

Saktiņa, D. and W.H. Meyers (2007) Targeting development policies for lagging rural areas: Latvia case study. Žemès ūkio mokslai 14 (Priedas) pp. 116-122.

Scoones, I. (1998) Sustainable rural livelihoods: a framework for analysis (Brighton: Institute of Development Studies).

Sinnott, E. and J. Koettl-Brodmann (2015) Aging with growth in Central Europe and the Baltics : what's next for old Europe? (Washington, D.C.: World Bank group).

Statistics Estonia (2017) Statistical database. Available: http://pub.stat.ee/px-web.2001/dialog/statfile1.asp [2019, May 27].

Statistics Latvia (2017) Statistics database. Available: https://data1.csb.gov.lv/pxweb/en/ [2019, May 27].

Statistics Lithuania (2017) Indicators database. Available: https://osp.stat.gov.lt/statistiniu-rodikliu-analize\#/ [2019, May 27].

Wegren, S.K. (2005) Rural adaptation in Russia (Abingdon: Routledge).

Žakevičiūtè, R. (2016) Socio-economic differentiation in post-communist rural Baltics. The case of three kolkhozes. Journal of Baltic Studies 47 (3) pp. 349-368.

Table 1. Rural livelihood sources in 1995-2009 by country

Table 2. Wage-based, farm-based and mixed livelihood diversification strategies among the researched households (One-Way ANOVA)

Figure 1. Livelihood portfolios and diversification strategies of the above and below poverty line households in the researched rural areas and their change 1995-2009

Appendix 1 Variables used in the article and their coding 
Estonia

Latvia

Lithuania

\begin{tabular}{|c|c|c|c|c|c|c|c|c|c|}
\hline & 1995 & 2009 & $(\text { diff. })^{i}$ & 1995 & 2009 & (diff.) & 1995 & 2009 & (diff.) \\
\hline Livelihood sources, all (mean) & $2.57^{* * * *}$ & $2.34^{* * * *}$ & $(-.23)$ & $3.45^{* * *}$ & $3.08^{* * * *}$ & $(-.37)$ & $1.96^{* * * *}$ & $1.81^{* * * *}$ & $(-.15)$ \\
\hline Diversifying households, DH (\%) & 74.6 & 71.6 & $(-3.0)$ & 98.4 & 93.8 & $(-4.6)$ & 57.7 & 50.0 & $(-7.7)$ \\
\hline Livelihood sources, DH ${ }^{\mathrm{iii}}$ (mean) & 3.10 & 2.88 & $(-.22)$ & 3.49 & 3.22 & $(-.27)$ & 2.67 & 2.62 & $(-.05)$ \\
\hline Wages (\%) & 77.6 & 78.5 & (.9) & 57.8 & 61.9 & $(4.1)$ & 65.4 & 61.5 & $(-3.9)$ \\
\hline Social benefits (\%) & 56.7 & 43.1 & $(-13.6)$ & 78.1 & 57.1 & $(-21.0)$ & 26.9 & 26.9 & - \\
\hline Family farms (\%) & 44.8 & 35.4 & $(-9.4)$ & 84.4 & 77.8 & $(-6.6)$ & 46.2 & 42.3 & $(-3.9)$ \\
\hline Nature products $(\%)$ & 43.3 & 38.5 & $(-4.8)$ & 50.0 & 46.0 & $(-4.0)$ & 34.6 & 30.8 & $(-3.8)$ \\
\hline Entrepreneurship (\%) & 11.9 & 21.5 & (9.6) & 18.8 & 28.6 & $(9.8)$ & 7.7 & 3.8 & $(-3.9)$ \\
\hline Barter work (\%) & 11.9 & 13.8 & (1.9) & 26.6 & 19.2 & $(-7.6)$ & 3.8 & 3.8 & - \\
\hline Professional farming $(\%)$ & 6.0 & 4.6 & $(-1.4)$ & 20.3 & 14.3 & $(-3.7)$ & 2.5 & 1.3 & $(-1.2)$ \\
\hline Unofficial income $(\%)$ & 4.5 & 3.1 & $(-1.4)$ & 9.4 & 6.3 & $(-3.1)$ & 7.7 & 7.7 & - \\
\hline No income ${ }^{i i}(\%)$ & 3.0 & - & $(-3.0)$ & - & - & - & 3.8 & 7.7 & (3.9) \\
\hline Work abroad (\%) & - & 3.1 & $(3.1)$ & - & 1.6 & (1.6) & - & - & - \\
\hline
\end{tabular}

i Difference between 2009 and 1995 (2009-1995)

ii No income from any above listed sources

iii The differences are not statistically significant neither within nor between the countries

*** M ean livelihood sources are statistically different between countries at both points of time at the $p<.001$ level 


\begin{tabular}{|c|c|c|c|c|c|c|c|c|c|c|}
\hline \multirow[t]{2}{*}{ Factor } & \multicolumn{2}{|c|}{$\begin{array}{l}\text { Wage-based diversification } \\
\text { in } 2009(n=29)\end{array}$} & \multicolumn{2}{|c|}{$\begin{array}{l}\text { Farm-based diversification } \\
\text { in } 2009(n=33)\end{array}$} & \multicolumn{2}{|c|}{$\begin{array}{l}\text { Mixed diversification in } \\
2009(\mathbf{n}=51)\end{array}$} & \multicolumn{2}{|c|}{ ANOVA } & \multirow[b]{2}{*}{$\eta^{2}$} & \multirow[t]{2}{*}{$\begin{array}{c}\text { Scheffe Post } \\
\text { Hoc test }\end{array}$} \\
\hline & Mean & SD & Mean & SD & Mean & SD & $\mathbf{F}$ & $\mathbf{p}$ & & \\
\hline Livelihood sources count in 1995 (from 2 to 9) & 2.48 & 1.326 & 3.52 & 1.253 & 3.61 & .940 & 9.849 & .000 & .152 & $2>1,3>1$ \\
\hline Livelihood sources count in 2009 (from 2 to 9) & 2.31 & .541 & 3.33 & 1.021 & 3.51 & .925 & 18.374 & .000 & .250 & $2>1,3>1$ \\
\hline $\begin{array}{l}\text { Economic problems count }(0=\text { no problems, } \\
11=\text { eleven problems })\end{array}$ & 2.31 & 2.579 & 6.18 & 3.254 & 3.65 & 2.918 & 14.232 & .000 & .177 & $3>1,3>2$ \\
\hline Income per capita & 400.64 & 329.50 & 211.64 & 172.42 & 281.76 & 154.66 & 5.172 & .007 & .096 & $2>1$ \\
\hline $\begin{array}{l}\text { Direction of family's standard of living } \\
\text { (-1=downwards, } 1=\text { upwards) }\end{array}$ & .48 & .574 & -.03 & .684 & .43 & .728 & 5.897 & .004 & .097 & $1>2,3>2$ \\
\hline
\end{tabular}


A. Income sources of the above poverty line households in 1995 and 2009

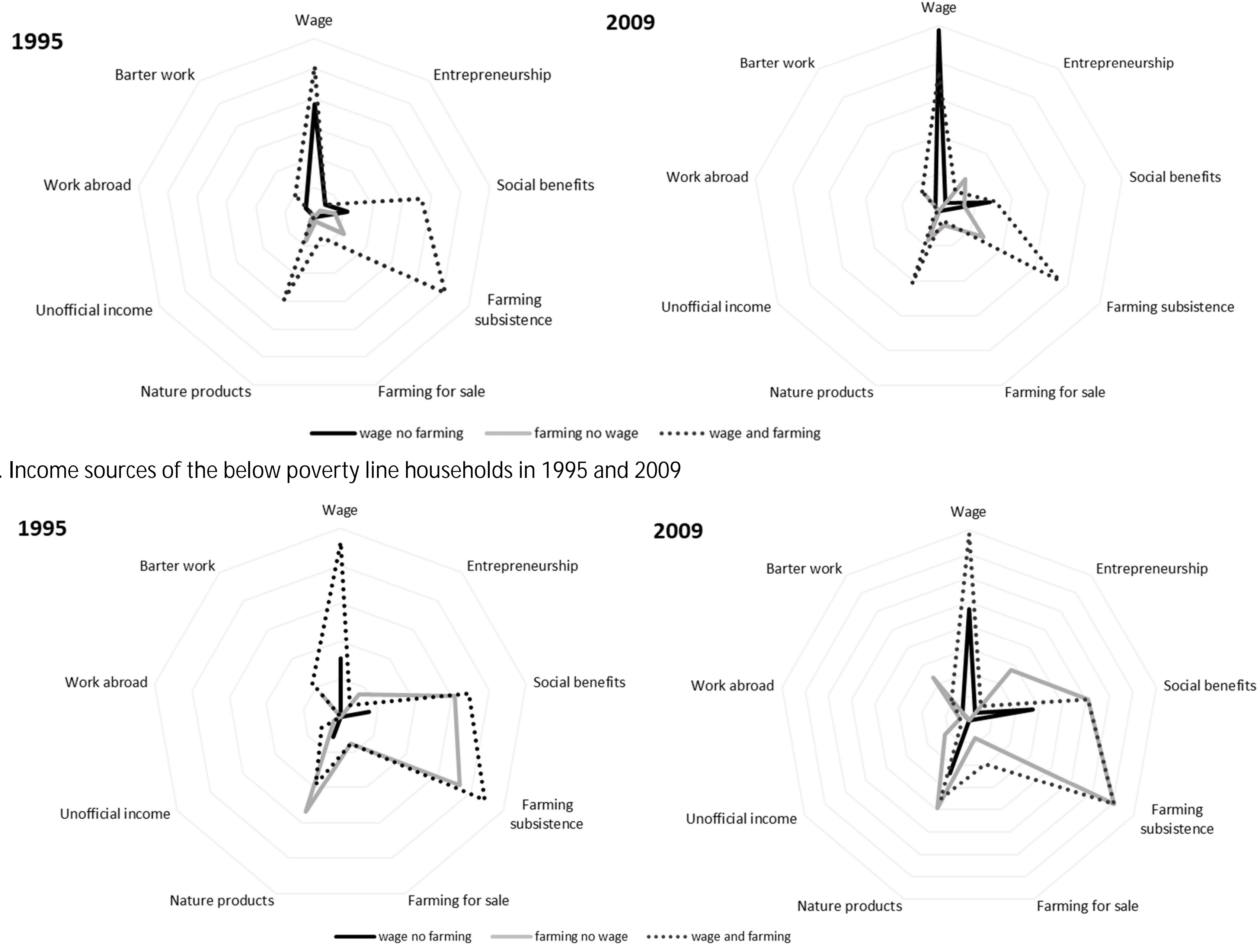




\begin{tabular}{|c|c|c|}
\hline Variable & Initial measurement & New codes \\
\hline Number of breadwinners & Number of breadwinners in the household & No changes \\
\hline Direction of family's standard of living & $\begin{array}{l}\text { 1. Upwards } \\
\text { 2. No essential changes } \\
\text { 3. Downwards }\end{array}$ & Scale -1 to 1 \\
\hline Received social income transfers & $\begin{array}{l}\text { (answer yes-no) } \\
\text { 1. Pensions } \\
\text { 2. Child benefits } \\
\text { 3. Unemployment benefits } \\
\text { 4. Care benefits } \\
\text { 5. Supplementary benefits } \\
\text { 6. The person did not have any listed income transfer } \\
\text { forms } \\
\text { 7. Stipend } \\
\text { 8. Other social income, what? }\end{array}$ & Benefit count $(0-7)$ \\
\hline Livelihood sources by the household & $\begin{array}{l}\text { (answer yes-no) } \\
\text { 1. Wage labour income } \\
\text { 2. Entrepreneur income } \\
\text { 3. Social income transfer } \\
\text { 4. Household plot farming additional } \\
\text { 5. Household plot farming professional } \\
\text { 6. Gathering nature products } \\
\text { 7. Unofficial income } \\
\text { 8. The person did not have any of the listed income forms } \\
\text { 9. Income from the seasonal/ short period work abroad } \\
\text { 10. Reciprocal work "barter" }\end{array}$ & Livelihood sources count (0-9) \\
\hline \multirow{2}{*}{ Household's income } & $\begin{array}{l}\text { Household's monthly monetary income in average after } \\
\text { taxes (amount in local currency) }\end{array}$ & $\begin{array}{l}\text { Amount in euros (converted using the } 2010 \\
\text { rate) }\end{array}$ \\
\hline & Amount (in euros) & $\begin{array}{l}\text { Equivalised disposable income: amount per } \\
\text { capita (in euros) }\end{array}$ \\
\hline Above-below poverty line & $\begin{array}{l}\text { Equivalised disposable income: amount per capita (in } \\
\text { euros) }\end{array}$ & $\begin{array}{l}\text { 1. Above poverty line } \\
\text { 2. Below poverty line (poverty line for each } \\
\text { country in 2010) }\end{array}$ \\
\hline Poverty groups & $\begin{array}{l}\text { Equivalised disposable income: amount per capita (in } \\
\text { euros) }\end{array}$ & $\begin{array}{l}\text { 1. Absolutely deprived ( } 1 / 2 \text { below poverty } \\
\text { line) } \\
\text { 2. Deprived ( } 50-75 \% \text { below poverty line) } \\
\text { 3. Relatively deprived ( } 75-100 \% \text { below } \\
\text { poverty line) }\end{array}$ \\
\hline $20 \%$ richest and poorest & $\begin{array}{l}\text { Equivalised disposable income: amount per capita (in } \\
\text { euros) }\end{array}$ & $\begin{array}{l}\text { 1. } 20 \% \text { richest - highest income quintile } \\
\text { 2. } 20 \% \text { poorest - lowest income quintile }\end{array}$ \\
\hline Land owned & $\begin{array}{l}\text { 1. Yes. How many hectares? } \\
\text { 2. No }\end{array}$ & Amount in hectares \\
\hline Farm size & Amount in hectares & $\begin{array}{l}\text { 1. No land (up to 0.99ha) } \\
\text { 2. Small farms (1-4.99ha) } \\
\text { 3.Average farms (5-19.99ha) } \\
\text { 4. Large farms (above 20ha) }\end{array}$ \\
\hline
\end{tabular}

